\title{
Intentionality and Commitment in Internationalization of Higher Education in the U.S.
}

\author{
Osman Özturgut \\ University of the Incarnate Word
}

Internationalization of higher education includes curriculum-research-service alignment that ensures that all students will be able to succeed professionally in a world marked by interdependence, diversity, and rapid change. Teaching, research, and service responsibilities of universities do not have national boundaries anymore. The alignment among these three responsibilities of higher education produces knowledge and higher thinking skills, enhances civic engagement, and results in positive social change. The culture in which internationalization succeeds are the ones that embrace the collective ability to admit weakness and prepare to confront the realities of the $21^{\text {st }}$ century to provide academic and financial accountability. Even if there is a high level of activity throughout the institution, albeit sporadic, without clear vision, intentionality, and commitment, it is bound to fail.

Keywords: international education, internationalization, higher education, globalization, global education

\section{INTRODUCTION}

Internationalization of higher education is not a new idea or concept. Since the first U.S. universities were created, there have been foreign language training programs (de Wit, 2002), and students and scholars have been mobile to and from U.S. institutions ever since (Altbach, 1998). However, these exchanges and programs were merely designed and supported to improve and help those seen as backwards, needing our help, and seeking improvement. Since then, internationalization has taken on new meanings, not necessarily agreed upon by all stakeholders involved, but its application has changed to be much more pragmatic. De Wit (2011b) confirmed:

When talking about internationalization, it is important to make the distinction between why we are internationalizing higher education, and what we mean by internationalization. Many documents, policy papers and books refer to internationalization, but do not define the why. And, in much of the literature, meanings and rationales are muddled in the sense that a rationale for internationalization is often presented as a definition of internationalization. (p. 244).

Altbach (2016) defined internationalization as the "specific policies and programs undertaken by governments, academic systems and institutions, and even individual departments to facilitate student and faculty exchanges, engage in collaborative research overseas, offer academic programs in English (or other languages)" (p. 84). Knight (2004) defined internationalization of higher education [emphasis added] as 
the "process of integration an international/intercultural dimension into the teaching, research and services functions of institutions" (p. 5) and that internationalization includes "academic standards, cultural diversity, student and staff development, and income generators" (p. 20).

Even though comprehensive internationalization has been marketed by universities as "a new indicator of excellence" (Harris, 2009, p. 348), there is relatively little meaningful curricular integration, nor adequate dedication of resources, to make global engagement an outcome that characterizes the education at higher education institutions. It stays within the framework of the core initiatives of student recruitment and basic academic collaboration (Brandenburg \& De Wit, 2011a). Naidoo and Jamieson (2005) posited that higher education has been treated as a commodity, similar to raw materials and manufactured goods, and this is true for the internationalization aspect of higher education as well. Importance of globalization have been magnified by the $21^{\text {st }}$ century realities and it has become imperative for universities to respond accordingly. Properly understood, internationalization of higher education is a curriculum-research-service alignment that ensures that all students will be able to succeed professionally in a world marked by interdependence, diversity, and rapid change. Teaching, research, and service responsibilities of universities do not have national boundaries anymore. This paper explores the institutions' understanding of internationalization and argues for a more focused alignment of teaching-research-service components, and how institutions' intentionality and commitment are crucial for successful comprehensive internationalization at U.S. higher education institutions.

\section{PROBLEM AND THE CONTEXT}

Comprehensive internationalization is a multidimensional process where teaching, research, and service activities are aligned to respond to the complex challenges of globalization and an increasingly multicultural world (Knight, 2004; Adams \& Paige 2005; Hudzik, 2011). The focus on the intersectionality of teaching, research, and service serves to respond to the needs of the communities we live and work in, both in local and global contexts. The alignment among three responsibilities of higher education produces knowledge and higher thinking skills, enhances civic engagement, and results in positive social change.

Burnett and Huisman (2010) conducted a study to understand how and why some higher education institutions have responded to aspects of globalization. Their qualitative research using a case study approach found that institutions' articulation of clear mission and business plan in support of internationalization and the top/down down/up culture of commitment, particularly commitment and support of senior administration, are crucial. Furthermore, they argued that targeted marketing and specialist roles with strong direct links to the academic core; a structure for international management (e.g., an international office with the right personnel), including the existence of direct leadership and effective champions, personnel incentives, policies and procedures, increased foreign language study, joint and double appointments for research, and engagement in strategic alliances are significant considerations for any institution committed to internationalization. Holzner and Greenwood (1995) argued that many higher education institutions do not have clearly defined, articulated, and operationalized strategies for comprehensive internationalization even though their mission statements articulate their intent and commitment to internationalization.

Comprehensive campus internationalization goes beyond languages, overseas campuses, and exchange programs. However, there is a lack of an inclusiveness where the alignment of teaching-research-service are clearly defined and articulated in the strategic planning at universities. Intentionality in planning of higher education internationalization and a sincere institutional commitment are imperative. This expansive and inclusive state will allow the universities to be organized hierarchically and harmoniously based on competencies expected of students to graduates to meet the needs of the global economies and communities as active citizens. As de Wit, Hunter, Howard, and Egron-Polak (2015) stated, it is " . . . the intentional process of integrating an international, intercultural, or global dimension into the purpose, functions, and delivery of post-secondary education, in order to enhance the quality of education and research for all students and staff, and to make meaningful contribution to society" (de Wit, Hunter, Howard, \& EgronPolak, 2015, p. 29). 
Internationalization is not necessarily an option or a co-curricular initiative, but it is a moral, intellectual, and professional imperative for all stakeholders involved. Institutionalized financial and administrative support and a systematic planning process and response to globalization that does not compromise the core values of the institution are needed for sustainability of any internationalization attempt. This paper first explains the challenges to internationalization for higher education institutions in regards to teaching/curriculum, research, and service as these three elements form the core of the mission for any higher education institution in the U.S. Latter section elaborates on the intentionality and commitment and provides guidance of how these three elements can be integrated within the internationalization framework.

\section{INTERNATIONALIZATION OF TEACHING AND CURRICULUM}

Svensson and Wihlborg (2010) explained that "There is no shared educational culture of teaching and learning concerned with internationalization" (p. 603). Huang (2006) and Killick (2009) explained that internationalization of curriculum is well recognized as an important indicator of higher education internationalization. Green and Shoenberg (2006) posit that "internationalizing the curriculum is the most important strategy institutions can use to ensure that all students acquire the knowledge, skills, and attitudes they will need as citizens and workers in a rapidly changing and globalized world" (p. iii). However, a misconception emerges and implies that internationalization of curriculum equals higher education internationalization (De Wit, 2011a). It simply goes beyond how we articulate internationalization in our syllabi, but it is important to consider the implications for how this internationalized curriculum is taught within the classrooms. As Maringe and Sing articulated, "the least developed strategy for the internationalisation of university environments is the internationalisation of the curriculum" (Maringe, \& Sing, 2014, p. 764).

Korhonen and Weil (2015) stated that "When it comes to teaching, internationalisation poses many changes and challenges" (p. 200). Language barriers, cultural differences are just few of the these challenges as Crose (2011) puts it, "Challenges exist with language barriers, differing learning styles, preconceived cultural traits, and the development of methods to effectively assess all students in a culturally diverse classroom"(p. 388). Crose further argued that even though the benefits of a diverse classroom, "Each culture that is represented possesses varying expectations, perceptions, and prejudices based upon their cultural norms and experiences" (p. 394) and that "Unless these differences are recognized and addressed, a true globalization of the classroom will not exist. Rather, students from different nationalities will co-exist in the same classroom, but intercultural learning will not occur" (p. 394).

Bamford (2008) and Lowe (2008) posit that many institutions believe that a culturally diverse student population can facilitate cross-cultural group experience as the international student population can be considered a source of knowledge, cultural responsiveness, and diversity; but Yen and Stevens (2004) and Bakalis and Joiner (2004) argue that domestic students are not necessarily interested in interacting with international students due to language, cultural or perceptual barriers. Brown (2009) confirms that domestic students do not have time or the patience to develop relationships with international students. This disconnect, of course, is not new and certainly not surprising given that less than $30 \%$ of U.S. postsecondary students complete a non-Western culture course, and only half of students are ever exposed to formal nonEnglish language instruction (Adelman, 2004). As Svensson and Wihlborg (2010) argued, "intercultural experiences and knowledge must become a part of teaching and learning, if higher education is to become internationalized" (p. 608). It is imperative that "teaching and learning take place on local and global scales as well as across geographical and cultural contexts" (Caniglia, John, Bellina, Lang, Wiek, Cohmer, \& Laubichler, 2018, p. 374).

\section{Internationalization of Research}

Stohl (2007) stated the importance of internationalization within the context of internationalizing the faculty and that in order for the university to internationalize the faculty, we "need to consider not only how to do what needs to be done but also how what needs to be done affects the faculty and how we can mobilize 
their power over the process" (p. 367). He argued that the institutional commitment and rethinking of the incentives and reward systems for faculty are crucial first steps in increasing faculty member's commitment to internationalization of research. To achieve this, "The reward structure includes not only salary but tenure. If the faculty does not value international learning, international research, international research collaboration, international development work, or international service it will not be rewarded" (p. 368). Without a clear and transparent connection of the reward systems, faculty members do not have incentives in international research, which can indeed be cumbersome as compared to conducting research on domestic issues or conducting research in local settings. International research then is considered "as a drag on productivity or as a less-competitive environment substituted in place of excellence" (Stohl, 2007, p. 368) and "researchers willing to collaborate internationally enter a complex set of relationships, marked by compromises with their departments, with their resource providers, as well as with their own research teams (Jones \& Oleksiyenko, 2011, p. 54).

\section{Internationalization of Service}

Internationalization of service is an area that is often overlooked or oversimplified simply to increasing the number of student experiences abroad. For example, the domestic component of involving international students in local service activities is often not a priority for higher education institutions in the U.S. Even though internationalization is "an outward process of positioning our institutions in global networks of learning, discovery, and engagement" (Sutton, 2010, p. 60), it is simplified for it to become and "an inward process of integrating international perspectives into our institutions" (Sutton, 2010, p. 60), in a superficial manner without any intentionality and a strong vision. The role of higher education institutions, whether public or private, is being responsive to the needs of the communities they are involved in and goes beyond a narrow scope of educating students for their first jobs. The public service that higher education institutions are responsible for includes educating the whole person that emphasizes global dimensions as an over compassing responsibility and strategic goal. In this context, the service activities should be integrated in a way that international students are intentionally integrated and the scope of such service activities goes beyond the national borders.

\section{INTENTIONALITY AND COMMITMENT}

For the purpose of this paper, I define intentionality as the institution's vision to provide a comprehensive plan addressing the universities strategic priorities and promoting and showcasing the buyin from the executive administration. Commitment is defined as institution's overall support in providing the necessary resources and revisiting the organizational structure for this strategic vision to be realized. Both intentionality and commitment are necessary for internationalization to become effective producing output and outcome relevant to institution's mission and vision. However, in the cases of many higher education institutions in the United States, disconnect between intentionality and commitment, or the lack of connectivity and coherence is worrying.

\section{Intentionality - Commitment Disconnect}

Collins and Porras (2002) and Peters and Waterman (1982) asserted that the main component of organizational success is a strong vision. Next, when organizations align their strategic vision with their practices, it will help develop a shared understanding among members of the organization about what needs to be accomplished. However, Collins (2000) stated that "executives spend too much time drafting, and redrafting vision statements, mission statements, values statements, purpose statements, aspiration statements, and so on. They spend nowhere near enough time trying to align their organizations with the values and visions already in place" (n.p.). This is also true for higher education executives with the alignment of their visions, missions, and strategic goals to produce tangible results.

Lack of intentionality shows itself in the form of:

- lack of outcomes-based study abroad programming (both for students and faculty) to include funding, organizational structure and curricular integration; 
- lack of faculty buy-in and sustainable support measures; lack of organizational structure and clarity in faculty and staff hires; international-domestic student engagement, collaborative research;

- and most importantly the lack of institutional vision to provide the necessary resources and organizational structures to be more pro-active in responding to the needs of global economies and service imperatives.

It is, in essence, the missed opportunities in teaching, research, and service alignment to successfully engage in and meet the challenges of globalization, lack of planning, implementation, and sustainability indicators in such internationalization efforts. Internationalization then cannot go beyond sporadic engagement activities that do not produce measurable impact for students, faculty, staff, and global stakeholders. The research available also does not provide an in-depth understanding of how strategic plans address the internationalization efforts of individual institutions.

Even though colleges and universities are progressively investing more time and resources into restructuring operations to promote the internationalization agenda, these investment are not necessarily reflected in the outcomes and actual practice especially in the engagement of international and domestic students in which "the rhetoric of education internationalization hides the fact that intercultural interaction, in and outside the classroom, is not happening naturally" (De Vita, 2007, p. 165). This mismatch between rhetoric and experience adds to the lack of intentionality. Simply put, the mere presence of international students on campuses does not equal internationalization. For example, as de Wit (2011a) argues, in order for the mission of global engagement to be effective in campus engagement, international students must be integrated with domestic students both inside and outside the classroom. This has to be a meaningful collaboration, going beyond "doing 'good things' when they foster 'international nights' or help an international student with paperwork; however, this does not address the root of the problem expressed in the research which dates back to the late 1970s" (Özturgut \& Murphy, 2009, p. 379).

Lack of staff diversity is another issue directly tied with the lack of intentionality. Staff diversity refers to the "systematic and planned commitment by institution/organization to recruit, retain, career development, reward, and promote a heterogeneous mix of employees" (Ivancevich \& Gilbert, 2000, p. 75). Özturgut \& Murphy's review of higher education job announcements that identified expectations of an 'International Student Advisor,' or of 'Assistant Director/Director of International Student Services' found that "misunderstanding or lack of understanding stems also from the fact that the people hired to communicate with international student populations on campus are not necessarily required to have multicultural and intercultural communications skills" (p. 380). Given the mere focus on policy compliance for international students, faculty, visiting scholars, and joint degree and research programming, the meaning of internationalization becomes limited to complex and complicated transactions that are aimed at maintaining the compliance of institutions with the federal laws. "Moving from random to intentional internationalization requires institutions to engage in a strategic process that involves the development of a plan of action, achievement strategies, and assessment mechanisms" (Cornelius, 2012, p. 63). Regulations often dominate non-academic matters and institutions' goals are ambiguous and imprecise. Universities with dominant bureaucratic cultures find it harder to respond to the global markets whereas intentional and committed institutions will do this with relative ease (Davies, 2001).

Hser (2005) argued that "many university administrators do not support internationalization even though there is an increased awareness of the impact of global change on the university" (p. 39). Weil (2011) and Young (2006) explained that the indicators for internationalization at higher education institutions tend to focus on quantitative aspects to include proportion of international students, number of study-abroad programs, and number of sister school agreements with exclusive partners in teaching and research. Even though, an increasing number of higher education institutions are including a global component into their mission statements and strategic plans (Fischer, 2012), the allocation of resources, necessary curricula integration, and the organizational structures are not realigned to meet these strategic [quantitative] goals. Dominance of commercial interests and ideologies in internationalization (Brandenberg \& de Wit, 2011; Knight, 2011) have been alarming and institutions' metrics have been 'intentionally' aligned to meet these commercial interest and institutions specific ideologies. This lack of 
commitment to the systematic, sustained efforts to be responsive to the "requirements and challenges related to the globalization of societies, economy and labor markets" (Kreber, 2009, p. 2) has not necessarily been acknowledged.

Institutional commitment, in this case, is to be achieved within the framework of its dedication to the new ways of doing things. For example, internationalizing teaching-learning will require that professors transform themselves and that they are able to deal with ambiguities about how to meet diversifying needs (Ryan \& Louie, 2007). Ryan (2013) explained that internationalization requires new ways of teaching, learning and assessing, new ways of designing and delivering curricula, new ways of thinking and acting, and new ways of listening. As progressive as higher education sounds, the hierarchical and traditional structure in higher education see new ways of doing things as threatening to the very essence of an elitist structure. For example, internationalization of curriculum has been considered critical to educating global citizens ( Paige, 2003; Huang, 2006), but, Siaya and Hayward ( 2003) found that only 20\% of research institutions require the study of another language for all undergraduate students and very few universities have university-wide international or global perspective course requirements. "Such a lack of coherence leads to different steering criteria, inconsistent quality approaches and a blurred picture of what constitutes an international teaching situation (Korhonen \& Weil, 2015, p. 199). Another example is that institutions championing for internationalization do not necessarily provide appropriate tenure and promotion structures and their institutional policies and procedures discourage international work (Dewey \&Duff, 2009; Green, 2007). Furthermore, Welikala's (2011) study confirmed that current practices in internationalization of higher education institutions favored "pedagogic approaches which emphasize ethnocentric-Western-didacticism encouraging assimilation and socialization of international learners to the learning approaches and theoretical perspectives advocated by the host university" (p. 15). This is an indicator how the connection between colonization and globalization continues to exist, through new economic and cultural relations (Prasad, 2003; Smith, 2006).

Even though internationalization has become a multi-billion dollar business for developed countries, it is still considered as "the 'white knight' of higher education (compared to globalization)... and it has become a synonym of doing good" (De Wit, 2011a, p. 29). Many institutions see internationalization as a source of financial strength with the emergence of market or market-like mechanisms in the higher education system (Teixeira, 2006). Students are consumers (Healey, 2009), and universities need to respond to their customers accordingly. Partnerships are established but they are neither institutionalized nor sustained over the long term beyond the personal commitment of individual faculty or staff members. Even though these partnerships are contractual agreements, they do not necessarily operate at a certain scale of activity or do not lead to identified outputs and outcomes. The sustained partnerships are the ones that were established to support international student recruitment through course credit or pathway programs, which confirms that higher education is being forced into a state of commercialization (Couturier, 2005; Lyall \& Sell, 2006).

To increase the academic buy-in for global engagement, efficiency of programming, increased study abroad participation and to ensure the curricular integration (teaching-research-service alignment), many institutions in the U.S. are moving towards creating academic leadership structures to carry out the international agenda and provide strategic direction for global engagement for their institutions. This of course comes with many challenges and risk associated with this "complex and growing phenomenon" (Knight, 2007, p. 9). This complexity shows itself in the form of international engagement structures widely varying in their principal roles, alignment, duties and authorities (Proctor, 2016). "Many [international] offices may have little knowledge and particularly little control over the activities of faculty or others who regularly represent the institution's presence or reputation abroad" (p. 36) and that "given the limited flexibility of an office built for limited functions, it is easy to misapprehend challenges as insoluble, leaving the office immobile in the face of emerging opportunity" (p. 37). The challenge for such structures is that they are not provided with the resources and institutional commitment for sustained success and are not permitted to go beyond symbolic representation of the institutions' intention and commitment. Creating such structures is of course needed and is nothing innovative in this century, but the commitment that comes with resources and institutional positioning is difficult to achieve. 


\section{DISCUSSION AND CONCLUSION}

Researchers have stated that internationalization of higher education involves a large scope of services and activities conducted by universities to respond to the pressures of globalization (Altbach \& Knight, 2007; Bruce, 2009; Burnett \& Huisman, 2010). However, whatever the motivation is for internationalization, intentionally and commitment are the key elements for achieving the goal of internationalization. Universities are struggling to cope with each of the elements of internationalization individually as separate factors within their highly hierarchical organizational structures. There are of course issues with resource allocation, government policies, quality assurance for accreditation and for other local and national standards to include foreign credit recognitions, and lack of focus on the curricula (Maringe, 2009), but these are nothing unexpected of any new initiative for any organization. The challenge is not whether there are internal and external challenges, but it is lack of intentionality and commitment of higher education institutions. There is a need for purposeful action if universities want to build a vision for internationalization (Bruce, 2009) because "most colleges and universities continue to struggle to find a place in the globalized environment" (p. 4).

Jiang and Carpenter (2011) conducted a study to identify and critically evaluate key issues faced by institutions in their efforts to internationalize and identified several issues:

- Low efficiency of agreement/contract preparation

- Staff attitude - fear, uncertainty and stress

- Lack of staff development and training

- Partnership management - people and trust

- Faculty internationalization is additional workload

- Anglo-centric curriculum barrier - dilemma between standardizing own syllabus and designing new programs

- Communication and internal support

- Faculty priority

- Conflict between faculty's own purpose and marketing central priority of international initiatives

- International Office needs to work closely with faculties and improves student support. (p. 8)

These issues are not necessarily unique to one institution and one host-country within the context of international higher education, but it is relevant to western institutions setting strategic priorities for comprehensive internationalization. Changing demographics are increasingly challenging higher education systems and they do not only require integration of internationalization in the strategic plan as a core element, but also need to strategize how to align teaching-research-service functions for internationalization with necessary allocation of resources and contextually structured visionary academic leadership with the tools and the authority to succeed.

Knight (2004) and de Wit's (2002) model for strategic implementation of internationalization in higher education provides a direction for intentional and committed institutions with a call for action. First suggestion is that institutional governance structures should express their commitment and recognize internationalization in their mission statements and other policy documents. Second suggestion is that operations should be aligned by integrating internationalization goals into institution's functions. Third suggestion urges the institutions to provide necessary academic and non-academic support services for all global engagement activities. Fourth suggestion is to develop human resources policies aligned with internationalization goals with necessary incentives for faculty, staff, and students.

Visionary and innovative leadership with shared responsibility and flexibility at all levels of the institution contributes to institutions organizational competitiveness and enthusiasm and essentially establishes the framework for sustainable internationalization. Cornelius (2012) explained that strategically positioning internationalization at the institution shows the commitment of executive administration and "it sends a clear signal to all stakeholders and to the entire college or university community that this interest is relevant and that the administration stands ready to support it." (Cornelius, 2012, p. 50). The culture in 
which internationalization succeeds are the ones that embrace the collective ability to admit weakness and prepare to confront the realities of the $21^{\text {st }}$ century to provide academic and financial accountability. Even if there is a high level of activity throughout the institution, albeit sporadic, without clear concepts, intentionality, and commitment, it is bound to fail. For any internationalization attempts to succeed, effective leadership, credible and respected champions are needed (CVCP/HEFCE, 2000).

\section{REFERENCES}

Adams, R., Jr., \& Page, J. (2005). Do International Migration and Remittances Reduce Poverty in Developing Countries? World Development, 33(10), 1645-1669.

Adelman, C. (2004). Principal Indicators of Student Academic Histories in Postsecondary Education, 1972-2000. Washington, DC: U.S. Department of Education, Institute of Education Sciences.

Altbach, P.G. (2016). Global Perspectives on Higher Education. JHU Press.

Altbach, P.G., \& Knight, J. (2007). The internationalization of higher education: Motivations and realities. Journal of Studies in International Education, 11(3-4), 290-305.

Altbach, P.P.G. (1998). Twisted roots: The Western impact on Asian higher education. In P.G. Altbach, Comparative Higher Education: Knowledge, the University, and Development (pp. 55-80). Chestnut Hill, MA: Boston College Center for International Higher Education.

Bakalis, S., \& Joiner, T.A. (2004). Participation in tertiary study abroad programs: The role of personality. International Journal of Educational Management, 18(5), 586-591. http://dx.doi.org/10.1108/09513540410543420

Bamford, J. (2008). Strategies for improving international students' academic and cultural experiences of UK study. In R. Atfield \& P. Kemp (Eds.), Enhancing the International Learning Experience in Business and Management, Hospitality, Leisure, Sport, Tourism (pp. 58-67). Newbury: Threshold Press.

Brandenburg, U., \& de Wit, H. (2011). The end of internationalization. International Higher Education, $62,15-16$.

Brown, L. (2009). A failure of communication on the cross-cultural campus. Journal of Studies in International Education, 13(4), 439-454.

Bruce, G.R. (2009). Institutional design and the internationalization of U.S. postsecondary education institutions (Unpublished doctoral dissertation). The Ohio State University, Columbus, Ohio.

Burnett, S.A., \& Huisman, J. (2010). Universities' responses to globalisation: The influence of organisational culture. Journal of Studies in International Education, 14(2), 117-142.

Caniglia, G., John, B., Bellina, L., Lang, D.J., Wiek, A., Cohmer, S., \& Laubichler, M.D. (2018). The glocal curriculum: A model for transnational collaboration in higher education for sustainable development. Journal of Cleaner Production, 171, 368-376.

Collins, J. (2000, June). Aligning action and values. Retrieved September 9, 2016, from $\mathrm{http}: / / \mathrm{www} . j \mathrm{imcollins.com/article \_ topics/articles/aligning-action.html}$

Collins, J., \& Porras, J.I. (2002). Built to last: Successful habits of visionary companies. New York, NY: HarperCollins.

Committee of Vice-Chancellors and Principals of the Universities of the United Kingdom (CVCP) (London), \& Higher Education Funding Council for England (Hefce). (2000). The business of borderless education: UK perspectives. London: CVCP.

Cornelius, A.R. (2012). Intentional Internationalization of Higher Education: A Strategic Institutional Response To Globalization. Retrieved from Electronic Theses \& Dissertations (Paper 396).

Couturier, L.K. (2005). The unspoken is being undone: The market's impact on higher education's public purpose. New Directions for Higher Education, pp. 85-100. doi:10.1002/he.174

Crose, B. (2011). Internationalization of the Higher Education Classroom: Strategies to Facilitate Intercultural Learning and Academic Success. International Journal of Teaching and Learning in Higher Education, 23(3), 388-395.

Davies, J.L. (2001). The emergence of entrepreneurial cultures in European Universities. Higher Education Management and Policy, 13(2), 25-45. 
De Vita, G. (2007). Taking stock: An appraisal of the literature on internationalising HE learning. In E. Jones \& S. Brown (Eds.), Internationalising Higher Education. Abingdon: Routledge.

De Wit, H. (2002). Internationalization of Higher Education in the United States of America and Europe: A Historical, Comparative, and Conceptual Analysis. Westport, CT: Greenwood Press.

De Wit, H. (2011a). Trends, Issues and Challenges in Internationalization of Higher Education. Retrieved from http://www.carem.hva.nl/wp-content/uploads/2011/10/Trends-Issues-andChallenges_Hans-de-Wit1.pdf

De Wit, H. (2011b). Globalisation and Internationalisation of Higher Education [introduction to online monograph]. Revista de Universidad y Sociedad del Conocimiento (RUSC), 8(2), 241-248. Retrieved from http://rusc.uoc.edu/ojs/index.php/rusc/article/view/v8n2-dewit/v8n2-dewit-eng

de Wit, H., Hunter, F., Howard, L., \& Egron-Polak, E. (2015). Internationalisation of higher education. European Parliament, Committee on Culture and Education. Retrieved from http://www.europarl. europa.eu/RegData/etudes/STUD/2015/540370/IPOL_STU(2015)540370_EN.pdf

Dewey, P., \& Duff, S. (2009). Reason before passion: Faculty views on internationalization in higher education. Higher Education, 58, 491-504.

Fischer, K. (2012). In Rhode Island, an unusual marriage of engineering and languages lures students. The Chronicle of Higher Education. Retrieved May 21, 2011, from http://chronicle.com/article/AnUnusual-Marriage-of/131905/

Green, M.F. (2007). Internationalizing community colleges: Barriers and strategies. New Directions for Community Colleges, 138, 15-24.

Green, M.F., \& Schoenberg, R. (2006). Where faculty live: Internationalizing the disciplines. Washington, DC: American Council on Education.

Harris, S. (2009). Challenges and possibilities facing European higher education. Papers, Revista de sociologia, Department de Sociologia, Universitat Autónoma de Barcelona.

Healey, P. (2009). The pragmatic tradition in planning thought. Journal of Planning Education and Research, 28(3), 277-292.

Holzner, B., \& Greenwood, D. (1995). The institutional policy contexts for international higher education in the United States of America. In H. de Wit (Ed.), Strategies for internationalisation of higher education: A comparative study of Australia, Canada, Europe and the United States of America. Amsterdam, Holland:European Association for International Education.

Hser, M.P. (2005). Campus internationalization: A study of American universities' internationalization efforts. International Education, 35(1), 35-48.

Huang, F. (2006). Internationalization of curricula in higher education institutions in comparative perspectives: Case studies of China, Japan and The Netherlands. Higher Education, 51(4), 521539. http://dx.doi.org/10.1007/s10734-004-2015-6

Hudzik, J. (2011). Comprehensive Internationalization: From Concept to Action. NAFSA EPublications. Retrieved from http://www.nafsa.org/resourcelibrary/Default.aspx?id=24045

Ivancevich, J., \& Gilbert, J. (2000). Diversity Management: Time for a new approach. Public Personnel Management, 29(1).

Jiang, N., \& Carpenter, V. (2011). Market entry dynamic framework for higher education internationalization. Journal of International Education in Business, 4(2), 141-158. http://dx.doi.org/10.1108/18363261111189531

Jones, G.A., \& Oleksiyenko, A. (2011). The Internationalization of Canadian University Research: A Global Higher Education Matrix Analysis of Multi-Level Governance. Higher Education: The International Journal of Higher Education and Educational Planning, 61(1), 41-57.

Killick, D. (2009). Graduates and global citizens perspectives on teaching and learning. Paper presented at the Internationalization of the Curriculum Workshop, Regents College, London, 11th March.

Knight, J. (2004). Internationalization remodeled: Definitions, rationales and approaches. Journal for Studies in International Education, 8(1), 5-31.

Knight, J. (2007). Internationalization: Concepts, complexities and challenges. In International handbook of higher education (pp. 207-227). Springer Netherlands. 
Knight, J. (2011). Higher Education Crossing Borders: A Framework and Overview of New Developments and Issues. In R. Sakamoto \& D.W. Chapman (Eds.), Cross Border Partnerships in Higher Education: Strategies and Issues (pp. 16-41). New York and London: Routledge.

Korhonen, V., \& Weil, M. (2015). The internationalisation of higher education: Perspectives on selfconceptions in teaching. Journal of Research in International Education, 14(3), 198-212.

Lowe, M. (2008). More than study: Exploring relationship-building with overseas students. In R. Atfield, \& P. Kemp (Eds.), Enhancing the International Learning Experience in Business and Management, Hospitality, Leisure, Sport, Tourism (pp. 143-152). Threshold Press: Newbury.

Lyall, K.C., \& Sell, K.R. (2006). The de facto privatization of American public higher education. Change Magazine, 38, 6-13.

Maringe, F., \& Sing, N. (2014). Teaching Large Classes in an Increasingly Internationalising Higher Education Environment: Pedagogical, Quality and Equity Issues. Higher Education: The International Journal of Higher Education and Educational Planning, 67(6), 761-782.

Naidoo, R., \& Jamieson, I. (2005). Empowering participants or corroding learning? Towards a research agenda on the impact of student consumerism in higher education. Journal of Educational Policy, 20(3), 267-281.

Özturgut, O., \& Murphy, C. (2009). Literature vs. practice: Challenges for international students in the U.S. International Journal of Teaching and Learning in Higher Education, 22(3), 374-385.

Paige, R.M. (2003). The American case: The University of Minnesota. Journal of Studies in International Education, 7(1), 52-63.

Peters, T., \& Waterman, R. (1982). In search of excellence: Lessons from America's best-run companies. New York, NY: HarperCollins.

Prasad, A. (2003). Postcolonial theory and organizational analysis: A critical engagement. Springer.

Proctor, D. (2016). The Changing Landscape of International Education Research. International Higher Education, (84), 19-21.

Ryan, J. (2013). Introduction. In Ryan J (ed.) Cross-Cultural Teaching and Learning for Home and International Students (pp. 1-12). London: Routledge.

Ryan, J., \& Louie, K. (2007). False Dichotomy? 'Western' and 'Confucian' concepts of scholarship and learning. Educational Philosophy and Theory, 39(4), 404-417.

Siaya, L., \& Hayward, F. (2003). Mapping internationalization on U.S. campuses. Washington, DC: U.S. Council on Education.

Smith, D.G. (2006). Trying to teach in a season of great untruth: Globalization, empire and the crises of pedagogy (Vol. 2). Sense Publishers.

Sutton, S. (2010). Transforming Internationalization through Partnerships. International Educator, 19(1), 60-63.

Svensson, L., \& Wihlborg, M. (2010). Internationalising the Content of Higher Education: The Need for a Curriculum Perspective. Higher Education: The International Journal of Higher Education and Educational Planning, 60(6), 595-613.

Teixeira, C. (2006). Residential segregation and ethnic economies in a multicultural city: The Little Portugal of Toronto. Landscapes of the Ethnic Economy, pp. 49-66.

Weil, M. (2011). Internationalisierung der Hochschullehre - rehabilitiert? In M. Weil, M. Schiefner, B. Eugster, et al. (Eds.), Aktionsfelder der Hochschuldidaktik (pp. 251-279). Münster: Waxmann.

Welikala, T. (2011). Rethinking international higher education curriculum: Mapping the research landscape. Universitas, 21.

Yen, W.J., \& Stevens, P. (2004). Taiwanese students' perspectives on their educational experiences in the United States. International Education Journal, 5(3), 294-307.

Young, B. (2006) Internationalisierung, Europäisierung und Virtualisierung der Hochschullehre: Interkulturelle Herausforderungen. In G. Simonis \& T. Walter (Eds.), LernOrt Universität. Umbruch durch Internationalisierung und Multimedia (pp. 253-280). Wiesbaden: VS. 